Click www.researchjournal.co.in/online/subdetail.html to purchase.

INTERNATIONAL JOURNAL OF PLANT PROTECTION

\title{
Growth and yield of oyster mushrooms (Pleurotus spp.) on organically amended agro wastes
}

\author{
Julie I. Elizabeth ${ }^{1 *}$ and T. Sheela Paul ${ }^{2}$
}

Regional Agricultural Research Station Ambalavayal, Ambalavayal, Wayanad (Kerala) India ${ }^{1}$ Department of Plant Pathology, College of Horticulture, Vellanikkara, Thrissur (Kerala) India

\section{ARITCLE INFO \\ Received : 28.07 .2020 \\ Revised : 05.09 .2020 \\ Accepted : 21.09 .2020}

KEY WORDS :

Pleurotus spp., Organic amendments, Rice bran, Dry azolla, Neem cake, Vermiwash, Dry biogas slurry

*Corresponding author:

Email : julie.elizabeth@kau.in

\begin{abstract}
The present experiment was conducted to identify the best organic amendment on the growth and yield of five species of oyster mushrooms viz.,Pleurotus florida, P. sajor-caju, P. eous, P. tuber-regium and Hypsizygus ulmarius by using organic amendments like rice bran, dry azolla, Neem cake, vermiwash and dry biogas slurry at three different concentrations. The effect of organic amendments on the number of days for sporophore formation, number and weight of sporophores varied according to the mushroom species. Results revealed that except dry biogas slurry, all organic amendments had superior effect in reducing number of days for sporophore formation, increasing the number of sporophores and yield. Effect of organic amendments on the yield of oyster mushrooms showed that all organic amendments except dry biogas slurry performed well with more number and weight of sporophores. The number of days for sporophore formation varied between 16.5 to 20.8 days in $P$. eous, 19.5 to 39 days in $P$. tuber-regium and 17.5 to 36.8 days in $H$. ulmarius. In P. florida and P. eous highest yield of $350.3 \mathrm{~g}$ and $379 \mathrm{~g}$, respectively obtained from paddy straw amended with 1 per cent Neem cake. P. sajor-caju gave the maximum yield of $405.3 \mathrm{~g}$ in 5 per cent rice bran. The maximum yield of $134.8 \mathrm{~g}$ was recorded in P. tuber-regium when treated with 4 per cent rice bran whereas paddy straw amended with 6 per cent dry azolla gave highest yield of $218.3 \mathrm{~g}$ in H. ulmarius.
\end{abstract}

How to view point the article : Elizabeth, Julie I. and Sheela Paul, T. (2020). Growth and yield of oyster mushrooms (Pleurotus spp.) on organically amended agro wastes. Internat. J. Plant Protec., 13(2) : 160-165, DOI : 10.15740/HAS/IJPP/13.2/160-165, Copyright@ 2020: Hind Agri-Horticultural Society. 